\title{
Sonographic Analysis of Calls and Behavioral Observations of the Black Woodpecker (Dryocopus matius) in Central Europe*
}

\author{
Ko Ogasawara**
}

\begin{abstract}
I have studied Black Woodpeckers (Dryocopus martius), especially with respect to behavioral observations, and through sonographic analysis of their calls, in central Europe (Gladenbach, Gammertingen, and Osnabrück in West Germany) from May 10 to the end of July 1985. I gave brief descriptions of habitats of Black Woodpeckers in Germany, followed by an analysis of sonagrams of kjäh-, kürr-, kwih-, and kijak-calls, and the drumming of Black Woodpeckers in West Germany. These analyses were followed by a discussion of the communications among male parent and his fledged female, and compared sonagrams of kijak-and kwih-calls of the young bird with those of adult.
\end{abstract}

\section{Introduction}

By the recently published vol. IV of the Handbook of the birds of Europe (Cramp 1985), calls of adult Black Woodpeckers (Dryocopus martius) are classified as follows.

1) Advertising-calls. These calls are represented by a series of 10-20 melodious 'Kwih' (quee) sounds.

2) Excitement-calls. These calls are loud with 2 variants given throughout the year and only when perched.

a) Long-drawn, more or less clearly disyllabic 'Kijäh' or 'Kjäh'.

b) Abrupt, incomplete and compressed sounding 'Klickje'.

3) Flight-calls. Long series of loud 'kürr', 'krü' or 'urr' sounds. Recording suggests a musical 'krrri krrri krrri' with rolled ' $r$ ' sound.

4) Threat-calls (kijak-calls). Series of quiet 'rürr' sounds given in short range threat between rivals or pairmembers of family after fledging.

Also, Blume $(1973,1976)$ and Bergmann \& Helb (1982) have described their calls in West Germany.

Ogasawara et al. $(1980,1981)$ have attempted to analyse the sonagrams of calls of Black Woodpeckers (Dryocopus martius) in Japan, and to compare preliminarily the sonagrams of some calls of the two populations of Black Woodpeckers between Germany and Japan.

Furthermore, Ogasawara (1983) pointed out the fact that the habitats of Black Woodpeckers in West Germany are almost the same as in Mt. Moriyoshi, Japan, both consisting of beech trees (Fagus silvatica in W. Germany, and Fagus crenata on Mt. Moriyoshi), but that the habitat in Hokkaido, consisting of Spruce forest (Abies sachalinesis), is quite different from the habitats in W. Germany and Mt. Moriyoshi. The Black

Received 10 April 1987

* This study was supported by a research grant from German Academic Exchange Service 1985.

** Department of Biology, College of Education, Akita University, Tegata, Akita 010, Japan. 
Woodpeckers have bred in the the Pinus silvestris forest in Germany as very rare case. The same author has postulated that the basic acoustical signals of Black Woodpeckers in Germany and Japan are somewhat different from each other, as revealed through the analysis of sonagrams.

The aim of the present study is to establish many detail sonagrams of Black Woodpecker's calls in relation to the behavioral meanings in Central Europe.

The ecological data and the recordings of Black Woodpecker's calls in West Germany come from the following areas (Fig. 1);

1) Gladenbach (Hessen); four territories during 10 to 12 May 1985, and during 16 to 19 May 1985.

2) Gammertingen; three territories during 13 to 15 May 1985 (Schwäbische Alb in Baden-Württemberg).

3) Osnabrück (Niedersachsen); one territory (Heger Holz), and many nesting sites, but young having already fledged in the end of May 1985.

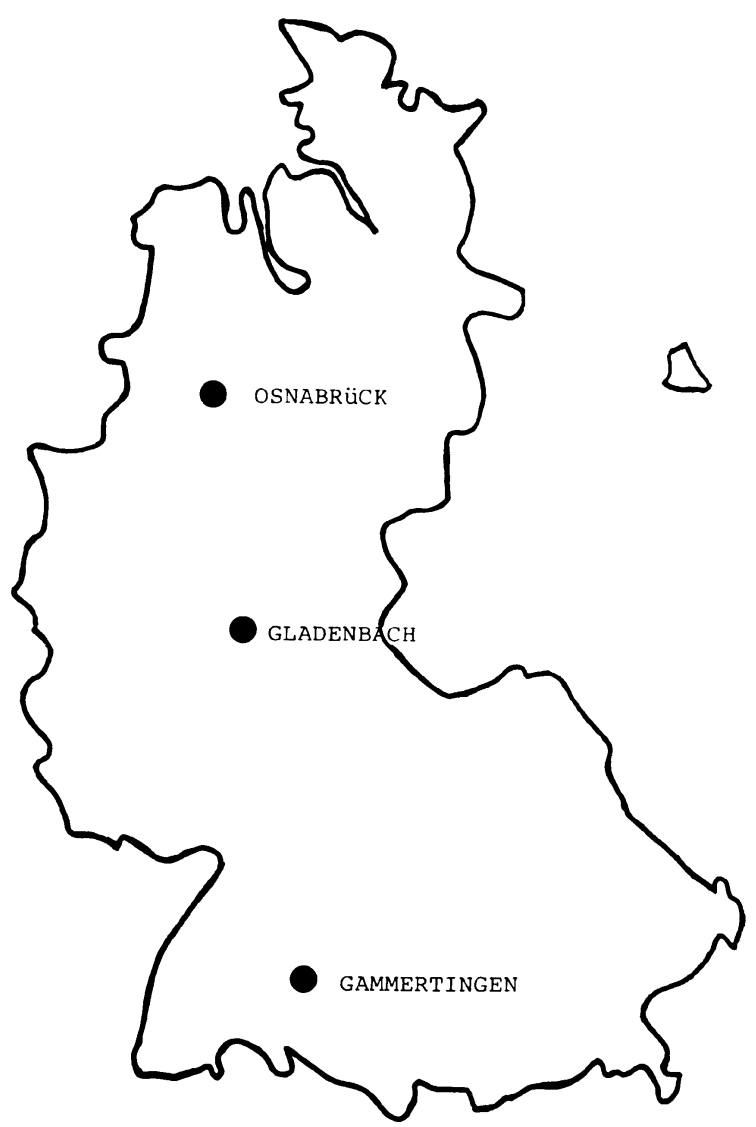

Fig. 1. The three study areas in W. Germany. 
Moreover, I could get some additional tape recordings of Black Woodpeckers from Germany; from Allensbach (Boden See) by Tilgner (1982), from Gladenbach (Hessen) by Blume (1960), from Gammertingen by Blume-Böhm (1985), from Stukenbrock/Senne by Conrads $(1968,1973)$, and Bergmann, Eastern Poland etc.

\section{Study Areas and Brief Descriptions of Habitats of Black Woodpeckers in West Germany}

I have mainly conducted my field studies of Black Woodpeckers in the following three areas in West Germany (Fig. 1).

1) Gladenbach: I visited four territories of Black Woodpeckers near Gladenbach with Mr. D. Blume and Mr. G. Kraft between 10-12th and 16-19th May, 1985 (Fig. 2).

Territory 1 (Fleckenstein/Kehlnbach)

This territory is located at $300 \mathrm{~m}$ above sea level, and is slightly inclined with brown soil. The beech (Fagus silvatica) forest inhabited by Black Woodpeckers is interspersed with some spruce (Picea abies) and oak trees (Quercus petraea), and wood-rush consisting of Luzula luzuloides (Vegetation type; Luzula-Fagetum).

There are two beech trees (about 120 years old) with holes of Black Woodpeckers. Hole no. 1 was built in 1979 and used for breeding in 1979-1985 (during 7 years). This hole is situated about 8 meters in height, and this tree is $158 \mathrm{~cm}$ in DBH. Additionally, another tree has not been used by Black Woodpeckers since 1979.

Nestlings of Black Woodpeckers (hole no. 1) are about 14 days old on 17 May 1985 (Blume, pers. comm).

Territory 2 (Driesberg/Teufelsberg)

This territory is located about $320 \mathrm{~m}$ above sea level, and is slightly inclined with brown soil. Forest with wood-rush (Luzula luzuloides) (Vegetation type: Luzula-Fagetum) inhabited by Black Woodpeckers is made up of about 150 years old beech trees. Beech trees in this forest have 8-10 m distance from each other, and are interspersed with some oaks (Quercus petraea).

Actually, there are no beech trees with nest holes of the Black Woodpecker, but one beech tree with an old nest hole is about 150 years old, and $175 \mathrm{~cm}$ in $\mathrm{DBH}$. It has not been clear where Black Woodpeckers have nested this year (Blume, pers. comm.).

Territory 3 (Am Berg/Herzhausen)

The beech forest used as nesting site by Black Woodpeckers is located about $450 \mathrm{~m}$ above sea level, and undergrowth in beech forest again consists of Luzula luzuloides (Vegetation type: Luzula-Fagetum).

The beech forest is located on the top of mountain, and beech trees are about 180 years old, and have $8-10 \mathrm{~m}$ distance from each other.

In this forest, I found five beech trees with nest holes of Black Woodpeckers (one with 8 holes, three with 2 holes, and one with one hole), and these holes were 10-40 years old. A pair of Black Woodpeckers were incubating on 16 May, 1985, the day of our visit (Blume, pers. comm.).

Territory 4 (Läusehardt/Rüchenbacher Hecke)

I only investigated the feeding sites of Black Woodpeckers in this territory. Many 


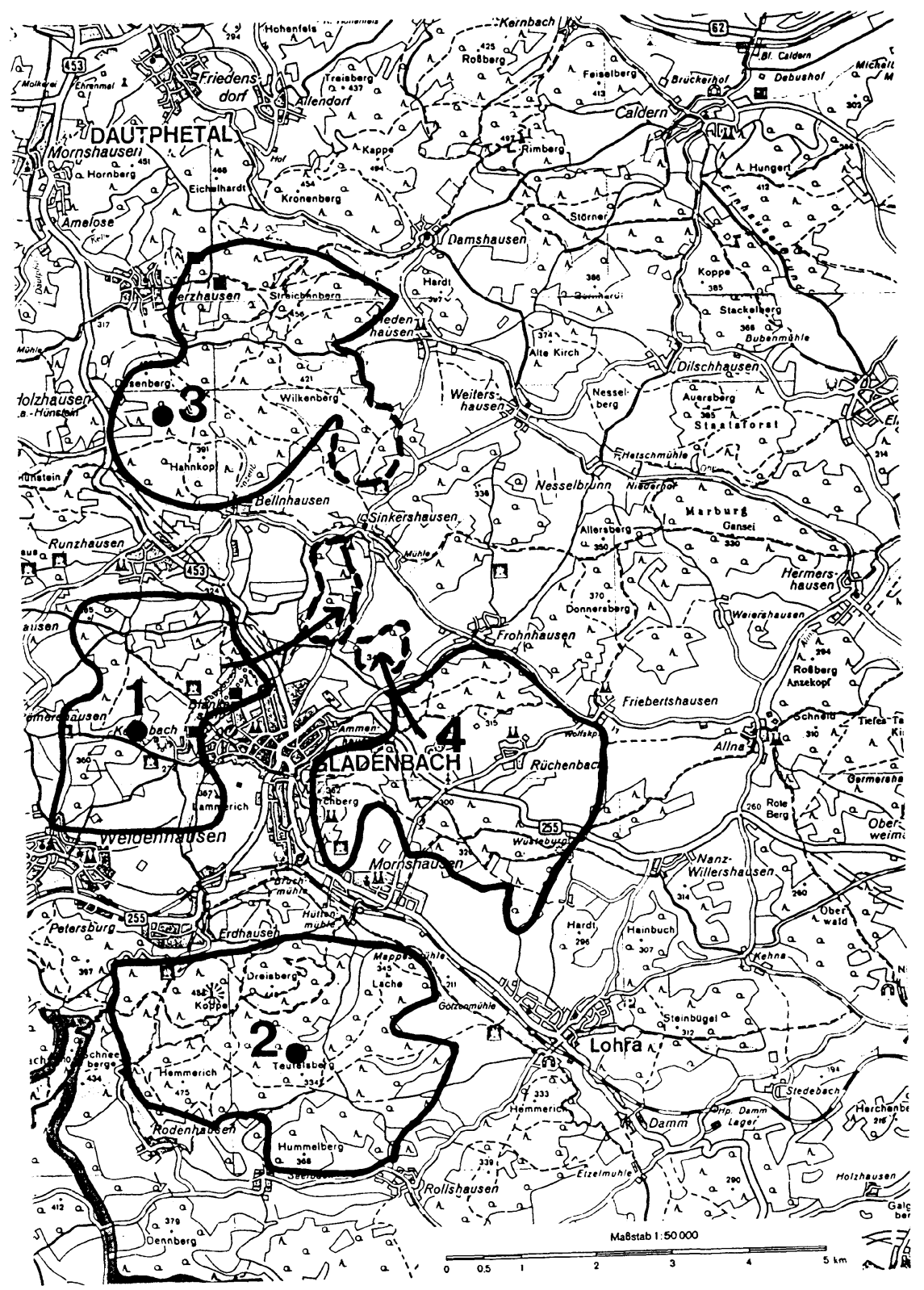

Fig. 2. The territorial map around Gladenbach drown by Dieter Blume.

feeding marks were found, and food, Cerambycidae, was taken from the feeding marks on stems of spruce and pine trees. Though Black Woodpeckers were present, nest holes could not be found in this territory.

2) Gammertingen

I visited Gammertingen in Schwäbische Alb, southern part of West Germany with 
Mr. D. Blume and his daughter (Mrs. Blume-Böhm) during 13 to 15 May. We surveyed three territories of Black Woodpeckers in Gammertingen.

Territory 1 (Der Grosse Brand)

This territory is located about $800 \mathrm{~m}$ above sea level on top of a mountain. The undergrowth of beech forest inhabited by the Black Woodpeckers consists of Dog's mercury (Mercurialis perennis) and Lathyrus vernus(Vegetation type: Lathyro-Fagetum).

This beech forest is made up of entirely old and young beech trees at different strata.

Four trees with nest holes of Black Woodpeckers were found, one of them with 6 holes. These were about 150-160 years old, and have 8-10 m distance from each other. These nest holes were occupied by various other birds, as follows:

beech tree one ....... young Jackdaws (Black Woodpecker's hole 1984).

beech tree two ......... young Jackdaws.

beech tree three ...... young of Tengmalm's Owl (Aegolius funereus), Black Woodpecker is incubating in a nesting hole.

beech tree four ....... young of Tengmalm's Owl.

Many feeding trees were found in the south part of this territory, and big feeding marks were found on Picea abies, and many ants (Campanotus herculeanus), a preferred food of Black Woodpeckers, were evidenced.

\section{Territory 2 (Hinterer Scheiterwald)}

This territory is located about $800 \mathrm{~m}$ above sea level, and on top of the mountain where many rocks of limestone are scattered. The forest consists of old beech trees with young beech trees forming the different strata. Dog's mercury (Mercurialis perennis) and Lathyrus vernus grow up in the undergrowth of beech forest (Vegetation type: Lathyro-Fagetum).

I could find three old trees of about 180-200 years old, one of which was $155 \mathrm{~cm}$ in DBH, and had 8 holes that were $20-30$ years old and occupied by 2-3 pairs of Jackdaws and one pair of Tengmalm's Owl (Aegolius funereus).

The nest sites of the Black Woodpeckers were unknown at present (Blume, pers. comm.).

\section{Territory 3 (Laucherthalde)}

This territory is located about $740 \mathrm{~m}$ above sea level, and other characteristics are the same as territory 2. The beech forest where Black Woodpeckers nested was mixed with Quercus, Acer, Pinus, and Abies. A beech tree on which Black Woodpeckers built their nest in 1984 was about $145 \mathrm{~cm}$ in DBH and 120 years old. Three to six days old nestlings were in the nest which was used as a nest hole in 1984.

3) Osnabrück

Heger Holz: There are many kinds of tree species in Heger Holz near the Osnabrück University; beech trees (Fagus silvatica), oak trees (Quercus petraea), pine trees (Pinus silvestris), and spruce trees (Picea abies), and small parts of this forest are deforested.

Behavioral observations of Black Woodpeckers were possible at many times, also some calls of Black Woodpeckers in Heger Holz were recorded.

I have observed a family of Black Woodpeckers (adult male and young female) that was feeding on stumps in the deforested area, in pine and spruce forests in Heger Holz 
several times.

Moreover, I have looked for the nests of Black Woodpeckers in many places near Osnabrück, but it is thought that nestlings already had left their nests in the end of May (Hadenhof Holz, Lezer Holz, Hüggel, Honeberg, Bramheide, Hollage, Suttheide, Willingholzhausen, Bissendorf, etc.).

4) Bielefeld (Nordrhein-Westfalen)

I visited two areas near Bielefeld to look for the nest of Black Woodpecker with Prof. Dr. H.-H. Bergmann, Dr. Conrads, and Mr. Siebrasse. One of them was the big and mature beech forest, in which a nest of a Black Woodpecker was found. Another was the despersed pine forest, in which a nest was found on a pine tree, but the nestlings had already fledged from their nest. It is very rare case that Black Woodpeckers build their nest on the pine tree in Germany (Dr. Conrads, pers. comm.). Also, Cuisin (1985) reported the Black Woodpecker very frequently excavates its nest in decideous trees (mainly beech Fagus silvatica, but also oak Quercus, poplar Populus and aspen Populus tremula, among others); extensive coniferous tracts are not, therefore, a sine qua non of its existence.

However, it is true that the nesting trees of Black Woodpeckers in Hokkaido, Japan, were almost all coniferous (Ogasawara 1985), because of a lack of beech trees in Hokkaido.

\section{Sonographic Analysis and Behavioral Observations of Black Woodpeckers in West Germany}

I have analyzed many calls of Black Woodpeckers in West Germany by sonographic method. Of these calls, the typical sonagrams of kjäh-calls, klickje-calls, kürr-calls, kwihcalls, and kijak-calls, and drumming of the Black Woodpeckers will be presented and given brief explanations.

1) Kjäh-calls

As described by Cramp (1985), kjäh-calls are very loud with the several variants given throughout the year, and are only given where Black Woodpecker is perched on the branch or on a stump.

Sonagrams of such kjäh-calls recorded in Osnabrück, Gladenbach, Gammertingen, and Allensbach (Tilgner 1982) of Germany are represented in Fig. 3.

It is recognized that these kjäh-calls had the variants as reported by Cramp (1985); that is, kijäh-calls is long drawn, more or less clearly disyllabic, and moreover, the klickjecalls as recognized from the tapes of Tilgner (1982), and from Osnabrück.

These kjäh-calls are obtained from tapes recorded near or on the nests of Black Woodpeckers in Gammertingen, Gladenbach, and Allensbach (Tilgner 1982), and in feeding sites of Heger Holz in Osnabrück.

Sonagrams (A-C) obtained from records in Osnabrück 1985 are kjäh-, and klickjecalls, and sonagrams (D-G) obtained from records of Allensbach by Tilgner (1982) are also kjäh-, klickje (E), and kli-calls (F-G), as shown in Fig. 3.

A sonagram of kijäh-call recorded in Gammertingen of the southern part of West Germany is shown in Fig. 4. It is thought that kijäh-, klickje-, and kli-calls are the 

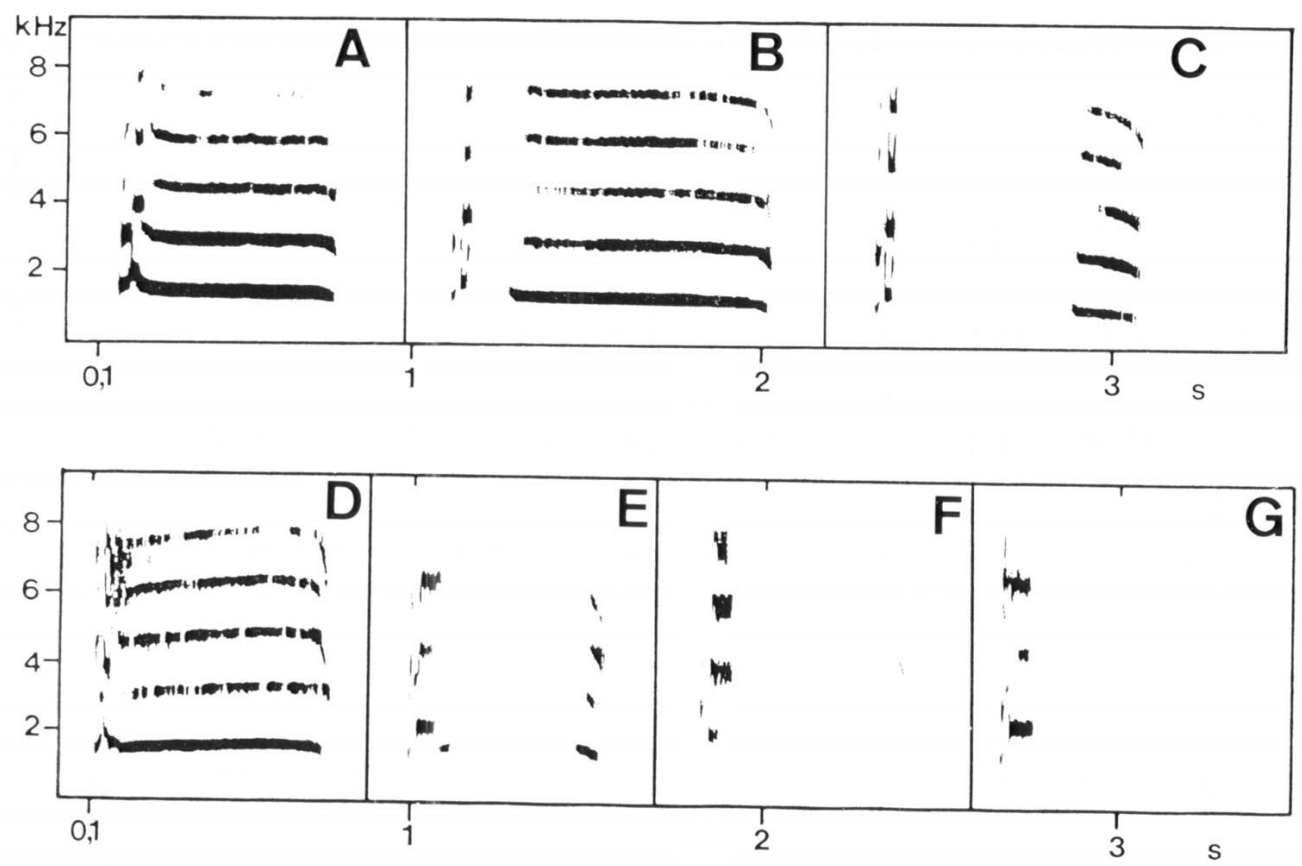

Fig. 3. Sonagrams and their variations of Kjäh-calls:

A: Kjäh, B: Kijäh, C: Klickje in Osnabrück 1985.

D: Kjäh, E: Klickje, F: Kli, recorded by Tilgner (in Allenshach 1982).

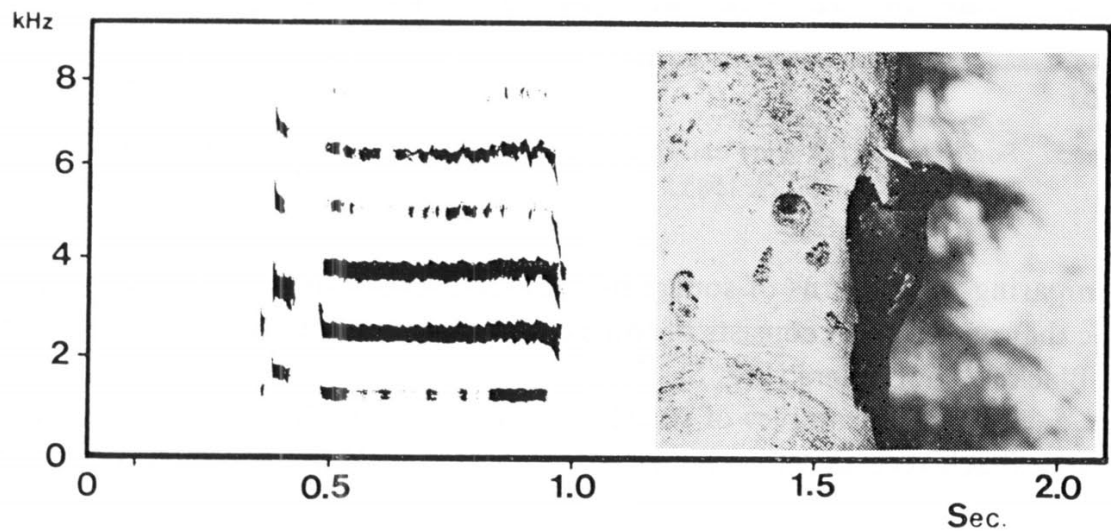

Fig. 4. Sonagram of Kijäh-call in Gammertingen 1985.

variants of kjäh-call as shown in Fig. 3 .

It is clear that these sonagrams of kijäh-calls in Gammertingen are somewhat more vibratory than the sonagrams of Osnabrück as shown in Fig. 4.

2) Kürr-calls

Kürr-calls are typical flight-calls, and are a long series of loud sounds, and heard near the nest hole, roosting hole, and also in the feeding sites. 

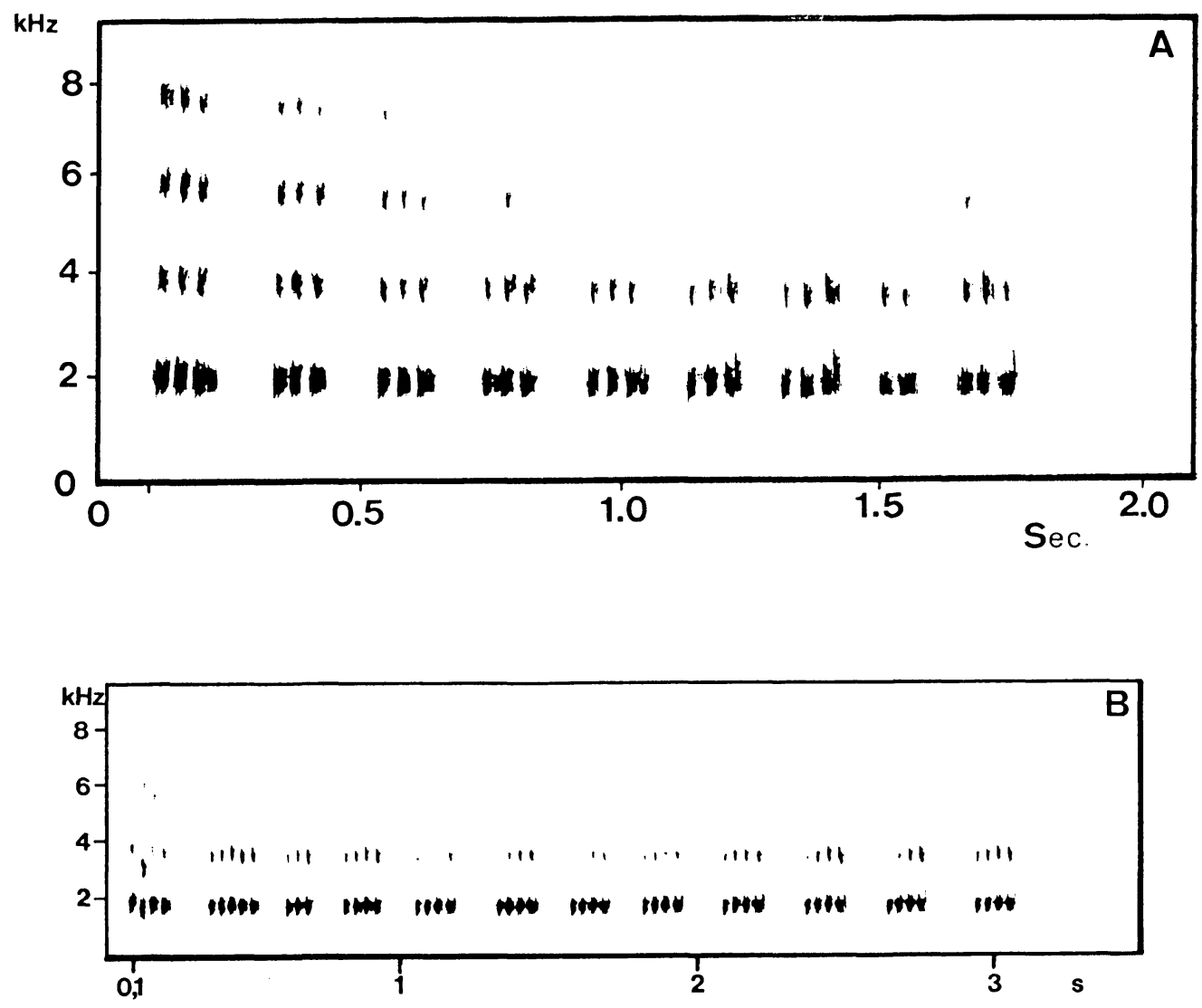

Fig. 5. Sonagram (A) of Kürr-call recorded by Tilgner (in Allensbach 1982), and of Kürrcall (B) in Osnabrück 1985.

Comparing the patterns of sonagrams between several areas of Germany, it is characteristic that one element consists of three or four subelements in the sonagrams of kürrcalls of Black Woodpeckers (Fig. 5).

Fig. 5 shows two examples of sonagrams of kürr-calls; that is, A in Fig. 5 is a kürrcall in Allensbach recorded by Tilgner (1982), and B in Heger Holz of Osnabrück 1985 (Fig. 5, B).

3) Kijak-calls

Kijak-calls are quiet and soft to hard, almost clicking, long drawn and more markedly disyllabic or short and explosive, and used for specific and sexual recognition; softer variants are given as greeting, harder ones to discourage close approach (Cramp 1985).

This call is frequently heard for contact between fledged young and male parent each other in Heger Holz of Osnabrück, and heard near the nest with the nestlings at the early date of leaving the nest in Hokkaido and Mt. Moriyoshi, Japan (Ogasawara, unpublished). 
Fig. 6 shows kijak-calls (A-B) and kwih-calls (C-D). A and B in Fig. 6 show the sonagrams of kijak-calls of adult male in Heger Holz, 23 June 1985. These kijak-calls are recorded in communication with his fledged offspring (female).

4) Kwih-calls

I have only several kwih-call series from Heger Holz near Osnabrück University, and from Gladenbach at present. Kwih-calls are advertising calls (Cramp 1985), and are made up of series of 10-20 melodious sounds.

Furthermore, these calls are frequently heard from the nestlings at an early date of leaving the nest and fledged young bird.

So, it is thought that these calls are used as the communications between the parent and its nestlings, and also fledged young birds.

Fig. 6 (C-D) shows the sonagrams of kwih-calls recorded by Conrads. These kwihcalls are clearly slow-pitch at first, and gradually high-pitch as shown in Fig. $6 \mathrm{C}, \mathrm{D}$.

5) Drumming

Drumming is associated with territory demarcation, attraction of sexual partner, nest-showing, and sexual stimulation, given by both sexes, mainly in February-August (Cramp 1985).

In study by Tilgner (1976), individual strikes are given at slightly slower rate by female, an average 14-15 strikes per second in female, 17 strikes per second in male (Fig. 7).

6) Calls of young after fledging (Heger Holz of Osnabrück)

I have frequently observed one young female Black Woodpecker after fledging with adult male in Heger Holz of Osnabrück (near Osnabrück University). During the be-

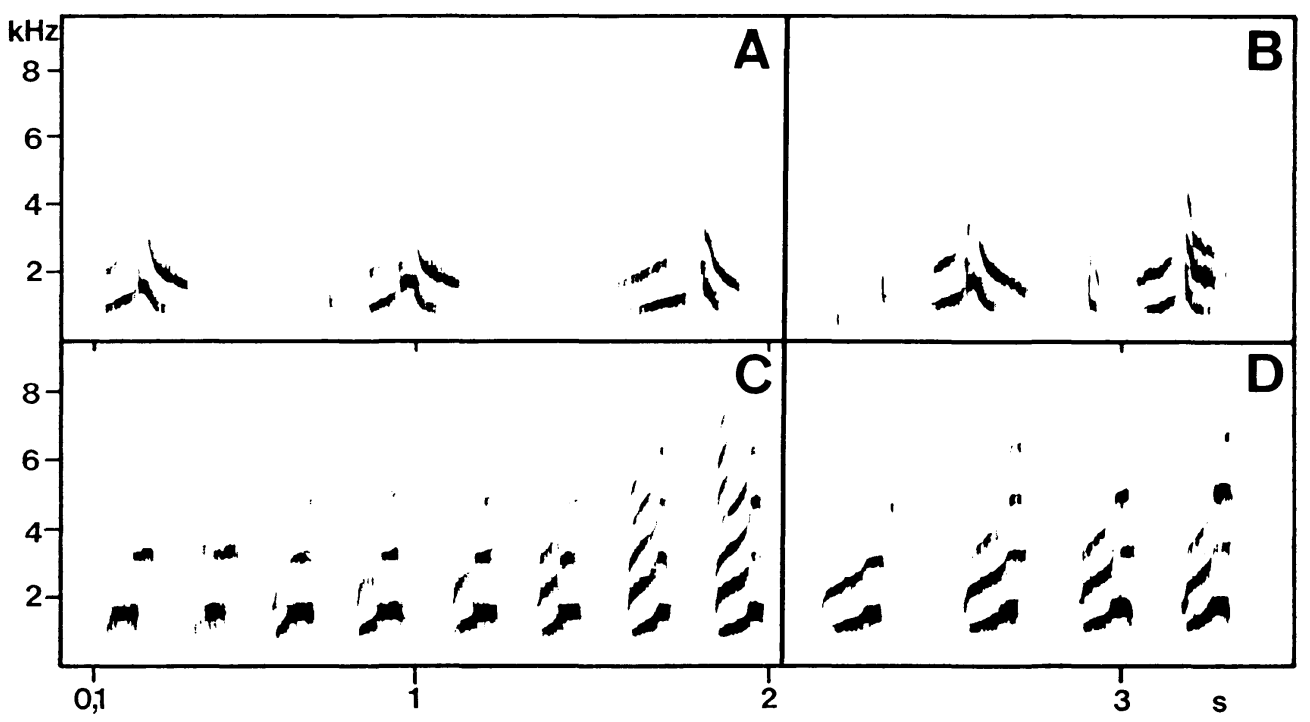

Fig. 6. Sonagrams of Kijak-calls (A, B) of the male adult in Heger Holz, Osnabrück, 23 June 1985, and of Kwih-calls (C, D) recorded by Conrads. 


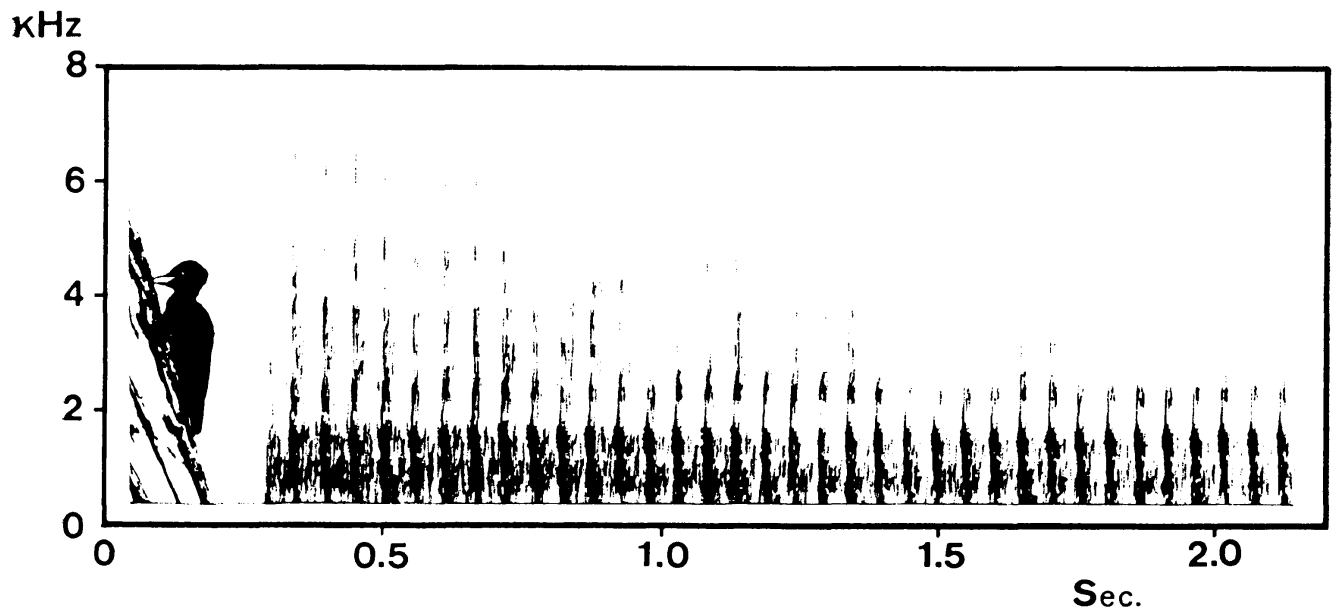

Fig. 7. Sonagram of drumming recorded by Tilgner (in Allensbach 1982).

havioral observations of this family, I could fortunately record some calls of communication between a young female and an adult male in Heger Holz.

It is very interesting that both calls, kwih and kijak-calls of young bird, apparently are undeveloped calls, as compared with those of adults (Fig. 8). So, both calls are very important to make clear the process of the development of the calls of nestlings and fledging young bird through the adult stage. Such a process of development of the

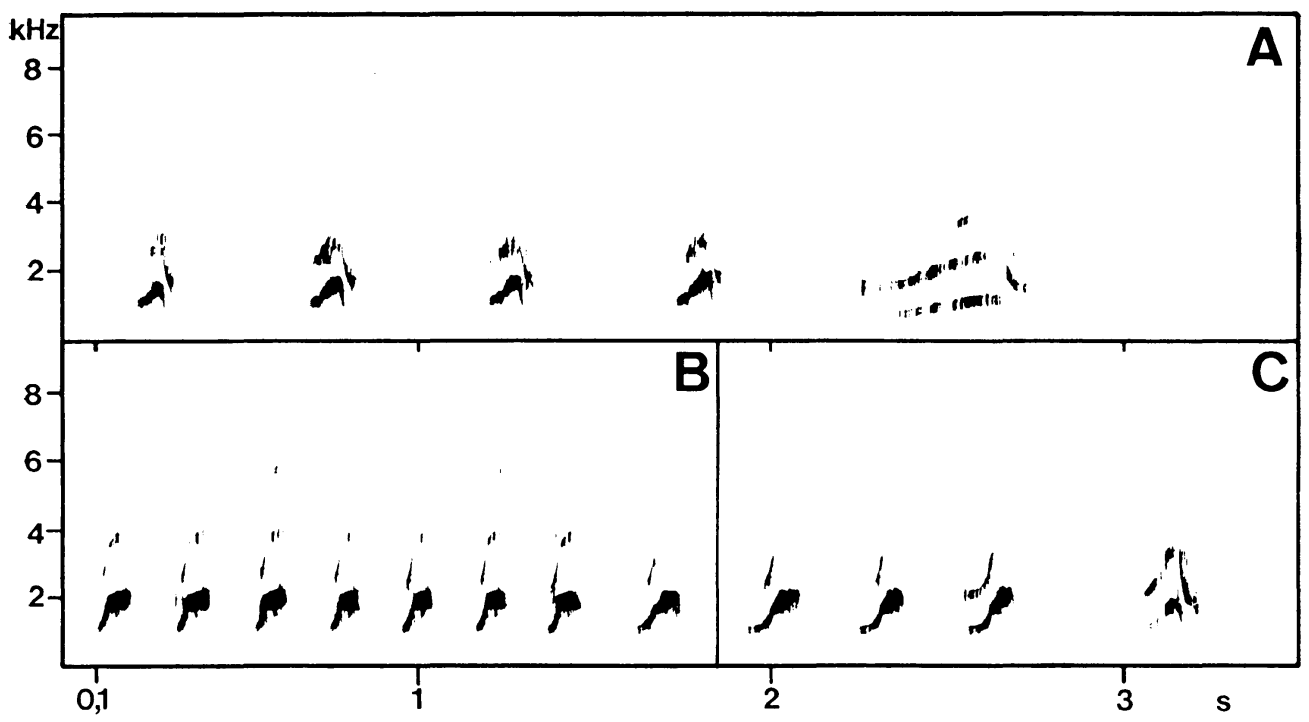

Fig. 8. Sonagrams of Kwih-Kijak calls (A), and of Kwih Kwih (B), and Kwih Kwih-Kijak calls (C) of the fledged young in Heger Holz, Osnabrück, 23 June 1985. 


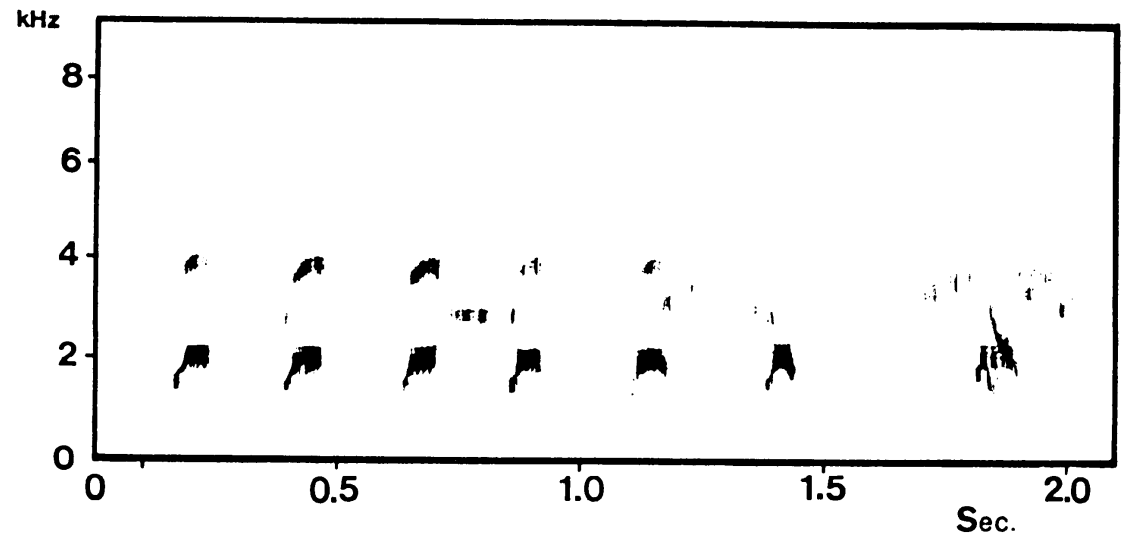

Fig. 9. Sonagrams of Kwih-Kijak calls of the fledged young bird in Heger Holz, Osanbrück,

nestling's calls has first been postulated in Japan by Ogasawara (1985).

I first observed the fledged young Black Woodpecker with her parent at 16:15, June 16 in Heger Holz. I observed a feeding adult male from 11:05 to 12: 40, and then he flew up to a branch of a pine tree, calling 'kjäh', and then flew into the bush of the deforested field with kürr-calls.

He fed on the old big stump from 12: 40 to $14: 20$, and flew off there at 14:20.

I could find again a feeding male on a trunk and on the ground at 15:45 in another place. Afterwards he flew up on the trunk of a pine tree, and flew down on the ground again. Immediately, the young female followed the male quietly and gave the begging calls (undeveloped kwih-calls). The male perched on the cut log and performed marked head-swaying behavior, and made kijak-calls.

Later, I could observe the behaviors of this family relatively for long-times; from 15: 20 to 19: 10 on June 18, from 15: 02 to 17:55 on June 21, from 13:15 to 15: 40 on June 22, and from 12:05 to 14: 35 on June 23, 1985, in Heger Holz, Osnabrück.

In these observations of this family, I could record many calls communicated between a fledged young bird and her male parent.

The male parent after feeding on the stumps in deforested areas or in spruce forest, would come flying toward his fledged female.

It was frequently observed that the male parent gave kijak-calls near his fledged female, and she responded with the same undeveloped kijak-calls (Figs. 8 and 9), and then, he went to the same tree where his fledged female was perched, and fed her.

However, male parent and his fledged female have fed sometimes together on the stumps in the spruce forest, but other times, the young bird has perched alone on the tree for a while, and given kwih- and kijak-calls.

It is very interesting that I have never heard the young bird giving kjäh- and kürrcalls throughout my observations.

This seems to suggest that kjäh- and kürr-calls have not yet developed in the young bird at the present time of the juvenile development. 


\section{Acknowledgements}

I express sincere thanks to Mr. Dieter Blume, Gladenbach, his family, and relatives, Mr. G. Kraft as well as Prof. Dr. H.-H. Bergmann of Osnabrück University, his coworkers and colleague, whose kindness and help allowed me to spend so much time in the field making observations, and to have a comfortable stay in West Germany.

I also would like to express appreciation to Prof. Dr. H.-H. Bergmann who gave me much valuable advice, in addition to giving me series of sonagrams of Black Woodpecker's calls, and helping me to have a productive and comfortable stay at Osnabrück University, and to German Academic Exchange Service which gave me the opportunity of studying the Black Woodpeckers in West Germany.

\section{References}

Bergmann, H.-H. \& Helb, H.-W. 1982. Stimmen der Vögel Europas. BLV Verlagsgesellshaft München Wien Zürich.

Blume, D. 1973. Schwarzspecht, Grunspecht, Grauspecht. Wittenberg-Lutherstadt: A. Ziemsen.

Blume, D. 1976. Uber die Lebens weise einiger Spechtarten (Dendrocopus major, Picus viridis, Dryocopus martius). Jour. für Ornith. 102: 1-115.

Cramp, S. 1985. Handbook of the Birds of Europe, the Middle East and North Africa, The Birds of the Western Palearctic. Vol. IV. Oxford.

Cuisin, M. 1985. Range-expansion of the Black Woodpecker in Western Europe. Brit. Birds 78: 184187.

Ogasawara, K. \& Izumi, Y. 1980. An attempt to analyze the vocalizations of the Black Woodpeckers by means of the Sound Spectrograph. Res. Rep. Ed. Technol. Fac. Ed., Akita Uni., 2: 17-20.

Ogasawara, K., Izumi, Y. Funaki, S. 1981. Examinations of the Basic Sound of Black Woodpeckers by the Sound Spectrograph. Res. Rep. Edu. Technol., College of Ed., Akita Univ. 3: 37-44.

Ogasawara, K. 1983. Breeding habitats and acoustical analysis of the Black Woodpecker's sounds in W. Germany and Japan. Res. Rep. Ed. Technol., College of Ed., Akita Univ. 5: 25-30.

Ogasawara, K. 1985. On the acoustical Communications of nestlings and parent of the Black Woodpeckers. Res. Rep. Ed. Technol., College of Ed., Akita Univ. 7: 27-30.

Tilgner, W. 1976. (from Cramp 1985).

\section{ヨーロッパ中部のクマゲラの声紋分析と行動の観察}

1985 年 5 月 10 から 7 月下旬の約 3 ケ月間, 中央ヨーロッパ (西ドイッのグラーデンバッハ, ガマテイ ンゲン及びオズナーブルック) にて, クマゲラの繁殖習性を観察し, さらに鳴き声を録音し, それらの声絞 分析に関する研究を行った。

調査地域のクマゲラの生息環境を記し，キャー (Kjäh), コロコロ (Kürr Kürr), クイッ (Kwih)やクック レア (Kijak) 音などクマゲラの持つ全音声のソナグラムを示し, それらの生態学的意義について考察した。 さらに,オズナーブルック市郊外で観察した巣立ち雛と雄親の交信を記載し，Kijak 音と Kwih 音のソ ナグラムを巣立ち雛と雄親の間で比較検討した。

小笠原 胃: 秋田大学教育学部. $\bar{\top} 010$ 秋田市手形学園町 1-1 


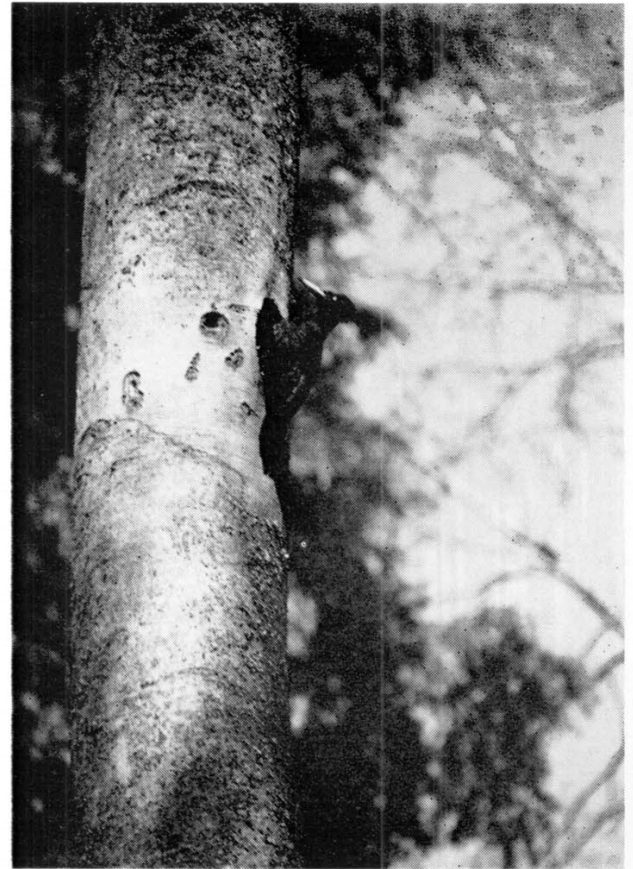

Photo. 1 Male Black Woodpecker at the nest hole in Gammertingen.

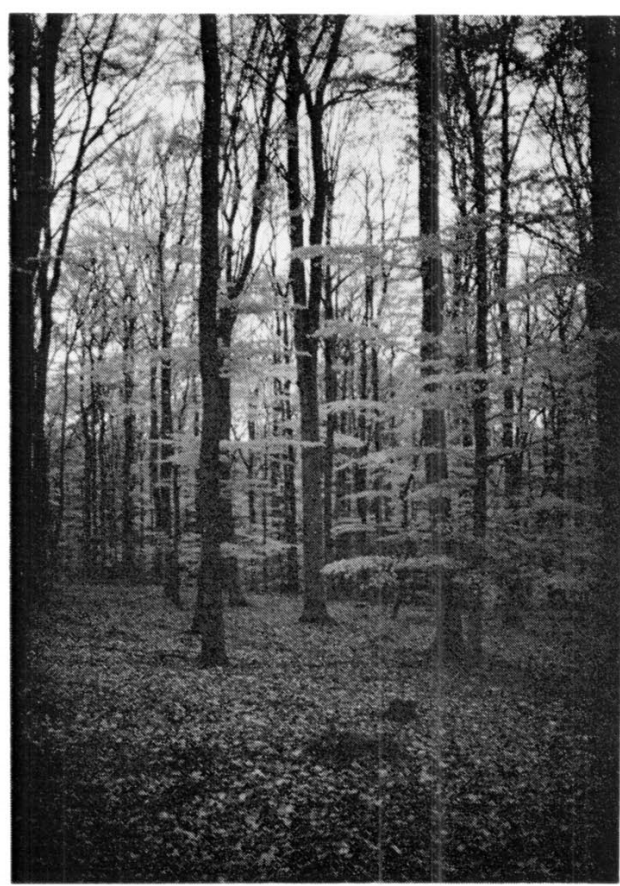

Photo. 3 Nesting habitat of Fagus silvatica forest in Gladenbach.

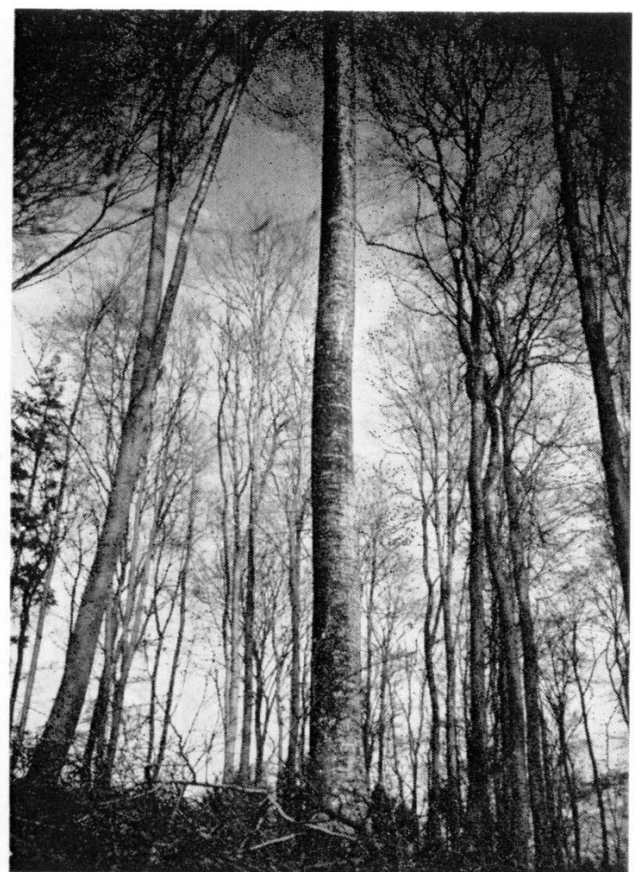

Photo. 2 Nesting habitat of Fagus silvatica forest in Gammertingen.

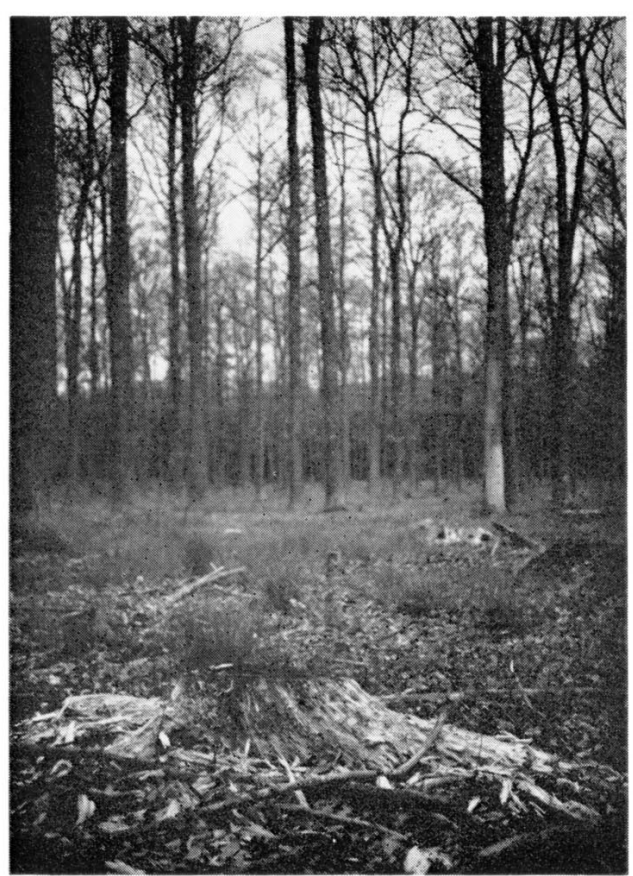

Photo. 4 A stump of Ouercus petraea fed by Black Woodpecker in Gladenbach. 


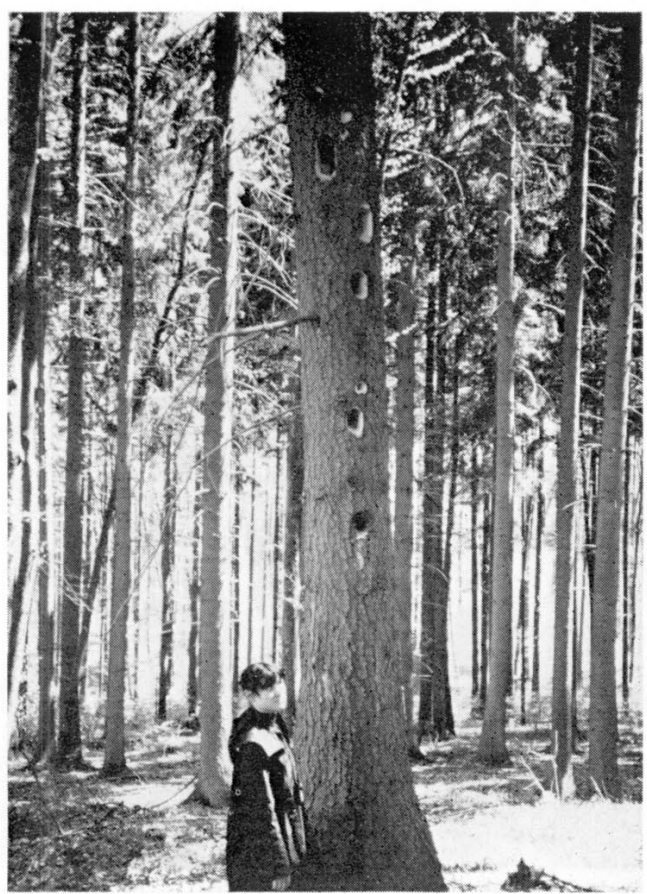

Photo. 5 Big feeding marks bollowed at winter on the Abies sachalinensis in Gammertingen. 